\title{
Retourmigratie en arbeidsmarktsucces van arbeidsmigranten
}

\author{
Govert Bijwaard*
}

De vraag of migranten bijdragen aan de economische groei van ons land speelt een sleutelrol in het migratiedebat. Het succes van immigranten op de arbeidsmarkt wordt meestal gemeten aan de hand van de arbeidsmarktpositie en de groei van hun inkomen tijdens het verblijf in het gastland.

Een groot deel van de arbeidsmigranten vertrekt weer uit ons land. Het is zeer waarschijnlijk dat de retourmigratie van arbeidsmigranten samenhangt met hun succes, arbeidsparticipatie en/of inkomen op de Nederlandse arbeidsmarkt. In deze bijdrage ga ik in op de relatie tussen retourmigratie en arbeidsmarktsucces, en bespreek ik de verschillende theorieën en de resultaten van empirisch onderzoek op basis van de instroom van arbeidsmigranten tussen 1999 en 2007 in Nederland.

In alle empirische analyses is zowel de verblijfsduur van de migranten in Nederland als de tijd in de verschillende arbeidsmarkttoestanden gemodelleerd in termen van een hazard-model. In deze modellen is expliciet rekening gehouden met selectie-effecten, door de verschillende hazards onderling afhankelijk te laten zijn.

Het empirisch onderzoek laat zien dat retourmigratie van arbeidsmigranten in Nederland deels verklaard kan worden uit target-savers-gedrag, succesvolle migranten die snel weer vertrekken, en deels uit retourmigratiegedrag gebaseerd op verkeerde arbeidsmarktverwachtingen, migranten die vertrekken nadat ze werkloos worden of een lage loongroei ervaren.

\section{Inleiding}

In hedendaagse maatschappelijke debatten wordt er meestal van uitgegaan dat immigranten permanent in Nederland zullen blijven. Dat was immers ook grotendeels het geval voor de gastarbeiders uit de jaren zestig van de vorige eeuw. De recent gearriveerde migranten zijn echter steeds minder geneigd om permanent in ons land te blijven dan de gastarbeiders. Een groot aandeel, meer $40 \%$, verblijft maar kort in Nederland, of migreert heen en weer tussen Nederland en het land van herkomst (Bijwaard, 2010; Hitzert \& Van Wijk, 2019). In economisch opzicht is het van belang om te weten of succesvolle migranten, werkend met een hoog inkomen, eerder vertrekken of minder succesvolle, werkloze migranten (Bijwaard, 2015). Daarnaast blijkt dat ook andere aspecten van de levensloop, zoals partnerschap, een belangrijke rol spelen in de verklaring van het vertrek (Bijwaard \& Van Doeselaar, 2014; Bijwaard \& Wang, 2016).

Door de vergrijzing van de Nederlandse samenleving zal arbeid in de toekomst steeds schaarser worden. Arbeidsmigratie is een van de mogelijkheden om krapte

* Govert Bijwaard is werkzaam bij het Nederlands Interdisciplinair Demografisch Instituut (NIDI), KNAW/Universiteit Groningen. E-mail: bijwaard@nidi.nl. 
op de arbeidsmarkt op te vangen. Vooral kennismigratie, de arbeidsmigratie van hoogopgeleiden, zal steeds belangrijker worden. Als deze migranten echter slechts voor korte tijd in ons land verblijven, wat geldt voor een ruime meerderheid, dan zal de potentiële bijdrage aan de Nederlandse economie van arbeidsmigranten beperkt zijn. Van deze migranten, die voornamelijk uit de EU en andere westerse landen komen, vertrekken de migranten met een hoog inkomen en uit de rijkere westerse landen sneller en vaker (Bijwaard, 2015; Bijwaard \& Wahba, 2014). Ook kennismigranten, waarvoor het een aantal jaren geleden gemakkelijker is gemaakt om naar Nederland te komen, vertrekken meestal snel.

In deze bijdrage ga ik in op de relatie tussen retourmigratie en arbeidsmarktsucces, en bespreek ik de verschillende theorieën en de resultaten van empirisch onderzoek naar deze relatie voor arbeidsmigranten in Nederland die tussen 1999 en 2007 naar Nederland zijn gekomen.

\section{Retourmigratietheorie}

Het overgrote deel van de (economische) literatuur veronderstelde tot voor kort dat migratie een eenmalige beslissing is (Borjas, 1999; Chiswick, 1978; Massey et al., 1993). Toch is zowel in de Verenigde Staten als in Europa de retourmigratie al lange tijd hoog. In de jaren zeventig van de vorige eeuw bleek al dat meer dan $50 \%$ van de immigranten in de Verenigde Staten binnen 10 jaar weer vertrekt (Jasso \& Rosenzweig, 1982). Voor de Europese landen zijn vergelijkbare cijfers bekend (Bijwaard, 2010; Dustmann, 1995).

Er bestaat een aantal concurrerende theorieën die de retourmigratie van arbeidsmigranten verklaren. Volgens de theorie van optimaal gepland verblijf is retourmigratie een geplande beslissing en maakt zij deel uit van een optimale strategie om het nut (inkomen) over de levensloop te maximaliseren, terwijl de migrant een voorkeur heeft voor consumptie in het land van herkomst (Dustmann, 1997, 2003; Dustmann \& Weiss, 2007; Galor \& Stark, 1991). Terugkeer van target savers, migranten die zich vooraf ten doel stellen om in het gastland een bepaald geldbedrag bij elkaar te sparen, is een specifiek voorbeeld: als het bedrag bij elkaar is gespaard, zal een dergelijke migrant terugkeren naar zijn land van herkomst. Deze theorie impliceert dat succesvolle arbeidsmigranten, werkend en met een hoog inkomen, eerder terugkeren dan minder succesvolle migranten. Zij kunnen immers in een kortere tijd meer geld bij elkaar sparen. Een tegengesteld mechanisme is gebaseerd op de theorie van verkeerde verwachtingen van de migrant over de arbeidsmarkt in het gastland. Volgens die theorie leidt een 'mislukking', werkloosheid of een laag inkomen, tot een ongeplande terugkeer (Borjas \& Bratsberg, 1996). In beide theorieën speelt het herkomstland een grote rol: zowel de fysieke als de culturele afstand heeft grote invloed op het retourmigratiegedrag. Als het land van herkomst op een grote afstand ligt, zijn de migratiekosten hoger. De culturele verschillen tussen het land van herkomst en Nederland bepalen hoe gemakkelijk het voor de migrant is om te integreren op de Nederlandse arbeidsmarkt en daarmee hoe groot de kans op succes is. Natuurlijk wordt de toegang van een arbeidsmigrant tot ons land ook bepaald door het herkomstland, aangezien arbeidsmigranten uit de Europese Unie zich vrij kunnen vestigen, terwijl dat voor arbeidsmigranten uit ontwikke- 
lingslanden een stuk moeilijker is. Daarnaast speelt het netwerk van al aanwezige migranten uit het land van herkomst een rol in het succes van de arbeidsmigrant.

\section{Individuele gegevens van arbeidsmigranten naar Nederland}

In het vervolg zullen de resultaten van een aantal recente publicaties over de relatie tussen retourmigratie en arbeidsmarktsucces van arbeidsmigranten in Nederland worden besproken (Bijwaard, 2010; Bijwaard, Schluter, \& Wahba, 2014; Bijwaard \& Wahba, 2014, 2019). Voor deze publicaties naar het retourmigratiegedrag van recente migranten in Nederland is gebruikgemaakt van een uniek databestand dat in samenwerking met het Centraal Bureau voor de Statistiek (CBS) is samengesteld op basis van administratieve gegevens. De informatie over migranten komt uit het Centraal Register Vreemdelingen (CRV) van de Immigratie en Naturalisatiedienst (IND) en de Gemeentelijke Basisadministratie persoonsgegevens (GBA), en betreft uitsluitend officiële, legale migranten. Deze migranten hebben zich door middel van inschrijving in de GBA formeel in Nederland gevestigd en hebben de intentie om ten minste 4 maanden in Nederland te blijven. Het gecombineerde GBA/CRV-bestand bevat gegevens over alle niet-Nederlandse immigranten van 18 tot 64 jaar die in de periode van 1999 tot 2007 naar Nederland zijn gekomen. Hieruit zijn alle officiële migratiebewegingen van ruim een half miljoen recente migranten naar en uit Nederland te volgen. Van deze migranten is bekend wanneer ze zich in Nederland vestigden en zich eventueel uitschreven, wat hun migratiemotief is, waar ze geboren zijn, hun leeftijd, hun geslacht, hun burgerlijke staat en of ze kinderen hebben. Deze informatie is gekoppeld aan sociaaleconomische gegevens uit het Sociaal Statistisch Bestand (SSB) van het CBS. Hierin staan op maandbasis onder andere de arbeidsmarktpositie, het inkomen, de sector waarin men werkt en of de migrant een uitkering ontvangt.

Ongeveer $31 \%$ van deze immigranten zijn arbeidsmigranten en $34 \%$ zijn familiemigranten ( $16 \%$ studenten, $13 \%$ vluchtelingen en $6 \%$ anders). In dit artikel beperken we ons tot de arbeidsmigranten (92.000 migranten), migranten die arbeidsmigratie als motief opgeven en binnen 3 maanden na aankomst daadwerkelijk werken. Deze migranten worden gevolgd vanaf het moment van aankomst in Nederland (ergens tussen 1 januari 1999 en 31 december 2007) en het moment van vertrek uit Nederland of tot 31 december 2007, voor de immigranten die dan nog in Nederland zijn. Op basis van hun geboorteland delen we deze arbeidsmigranten in vier herkomstgroepen: (1) EU-15-landen: migranten geboren in een van de 15 EU-landen die al voor 2004 in de EU zaten (53\%); (2) nieuwe EU-landen: migranten geboren in een van de landen die in 2004 of 2008 toegetreden zijn tot de EU (14\%); (3) westerse landen: migranten geboren in de EEA, Australië, Canada, Japan, Nieuw Zeeland, Verenigde Staten van Amerika, Zuid-Korea of Zwitserland (13\%); en (4) niet-westerse landen: migranten geboren in een van de andere landen (19\%).

Het aantal arbeidsmigranten naar Nederland is in het begin van deze eeuw sterk gestegen. In 1999 kwamen er ongeveer 15.000 arbeidsmigranten naar ons land. In 2007 is dit gestegen naar ruim 30.000 (inmiddels nog een stuk hoger). Uit figuur 1 blijkt duidelijk dat de instroom van arbeidsmigranten uit de nieuwe 
EU-landen (de landen die in 2004 en 2006 bij de EU kwamen) na toetreding sterk is toegenomen. Dit zijn vooral Polen. Ook de instroom van migranten uit de 'oude' EU-15, na een dip rond 2004, en uit niet-westerse landen is de laatste jaren sterk gegroeid.

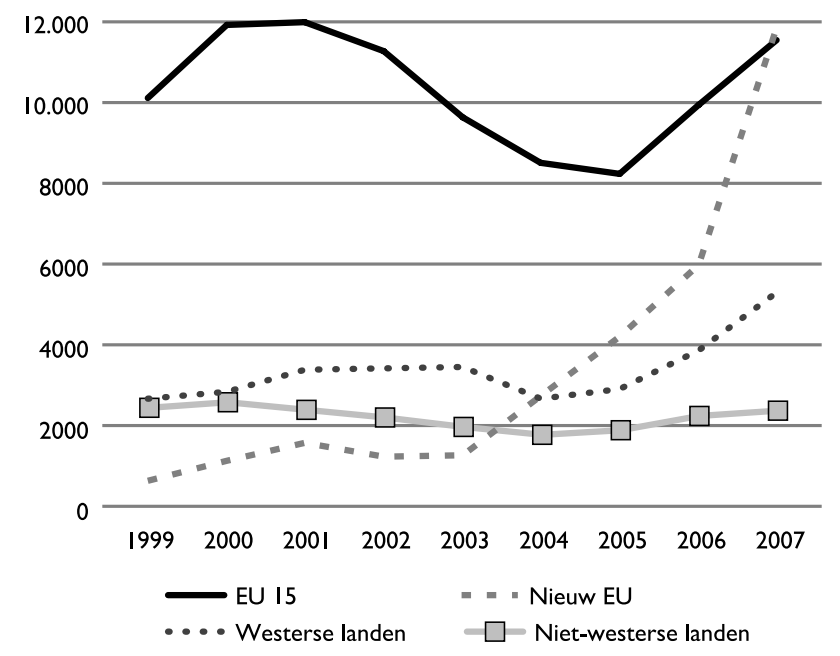

Figuur 1 Ontwikkeling van de instroom van arbeidsmigranten 1999-2007 Bron: CBS

Tabel 1 geeft een overzicht van de kenmerken van de arbeidsmigranten naar regio van herkomst. Het merendeel van de arbeidsmigranten is niet getrouwd, vooral de migranten uit de EU-15 niet, en van het mannelijke geslacht. De arbeidsmigranten uit de EU-15 en de nieuwe EU-landen zijn jonger dan de nietEU-migranten (met name uit de westerse landen). Van de arbeidsmigranten uit EU-landen (met name de nieuwe EU-landen) heeft een relatief groot deel, rond de $20 \%$, slechts een beperkt inkomen (minder dan $€ 1000$ per maand) bij aankomst in Nederland. Ruim een derde van de arbeidsmigranten uit westerse landen heeft een hoog inkomen (meer dan $€ 5000$ per maand). Ruim $40 \%$ van de arbeidsmigranten is werkzaam in de zakelijke dienstverlening. Alleen voor arbeidsmigranten uit westerse landen is dit iets lager.

Hoe succesvol, zowel qua arbeidsparticipatie als qua inkomen, de arbeidsmigranten op de arbeidsmarkt in Nederland zijn, heeft invloed op hun retourmigratiegedrag. Tabel 2 verschaft een samenvatting van het arbeidsmarktgedrag van de arbeidsmigranten in Nederland. Migranten uit de EU-15 zijn vaker en langer werkloos en vertrekken ook vaker als ze werkloos zijn. Figuur 2 toont hoe de arbeidsmarktpositie van de arbeidsmigranten, die bij aankomst allen werken, verandert met de verblijfsduur. Vijf jaar na aankomst in Nederland heeft ruim de helft van de arbeidsmigranten al een periode zonder werk in Nederland doorgemaakt, al dan niet met ondersteuning van een uitkering. Arbeidsmigranten uit de EU-15 worden vaker werkloos dan migranten uit andere regio's. Voor deze migranten is het gemakkelijker om zonder werk in ons land te blijven, omdat ze een werkloos- 
heidsuitkering kunnen aanvragen. Deze migranten vinden ook vaker weer nieuw werk in ons land. Van de arbeidsmigranten vertrekt $40 \%$ (westerse landen) tot $55 \%$ (EU-15) als ze werkloos zijn. Van de migranten in de steekproef heeft $75 \%$ werkervaring, heeft $71 \%$ een tijd zonder inkomen meegemaakt, is $20 \%$ minstens één keer een uitkeringsontvanger geweest en is $42 \%$ vertrokken binnen de waarnemingsperiode.

Tabel 1 Kenmerken van arbeidsmigranten 1999-2007 bij aankomst in Nederland (\%)

\begin{tabular}{lcccc}
\hline & EU-I5 & Nieuw EU & $\begin{array}{c}\text { Westerse } \\
\text { landen }\end{array}$ & $\begin{array}{c}\text { Niet- } \\
\text { westerse } \\
\text { landen }\end{array}$ \\
\hline Getrouwd & 17 & 26 & 42 & 29 \\
Vrouw & 33 & 30 & 22 & 22 \\
Jonger dan 25 & 21 & 26 & 10 & 16 \\
Leeftijd 25-30 & 30 & 31 & 23 & 32 \\
Ouder dan 40 & 16 & 15 & 28 & 16 \\
Inkomen $<€ 1000$ & 17 & 20 & 6 & 13 \\
Inkomen $€ 1000-€ 2000$ & 26 & 24 & 12 & 23 \\
Inkomen $€ 2000-€ 3000$ & 34 & 29 & 29 & 37 \\
Inkomen $€ 3000-€ 4000$ & 8 & 4 & 9 & 10 \\
Inkomen $€ 4000-€ 5000$ & 4 & 1 & 7 & 5 \\
Inkomen $>€ 5000$ & 12 & 2 & 38 & 12 \\
Werkzaam in de handel & 13 & 10 & 20 & 10 \\
Werkzaam in zakelijke dienstverlening & 43 & 44 & 34 & 46 \\
Werkzaam in industrie & 12 & 10 & 13 & 9 \\
\hline
\end{tabular}

Noot. De percentages zijn per herkomstgroep berekend.

Tabel 2 Arbeidsmarktgedrag tijdens verblijf in Nederland 1999-2007 (\%)

\begin{tabular}{|c|c|c|c|c|}
\hline & EU-I5 & Nieuw EU & $\begin{array}{c}\text { Westerse } \\
\text { landen }\end{array}$ & $\begin{array}{c}\text { Niet- } \\
\text { westerse } \\
\text { landen }\end{array}$ \\
\hline Altijd werkend & 50 & 64 & 65 & 63 \\
\hline Ix werkloos & 37 & 29 & 32 & 29 \\
\hline Werkloos bij vertrek ${ }^{\mathrm{a}}$ & 54 & 44 & 41 & 49 \\
\hline$<3$ maanden werkloos ${ }^{b}$ & 19 & 26 & 23 & 20 \\
\hline 3-6 maanden werkloos ${ }^{b}$ & 16 & 23 & 17 & 17 \\
\hline $6-12$ maanden werkloos ${ }^{b}$ & 23 & 23 & 20 & 22 \\
\hline$>12$ maanden werkloos ${ }^{b}$ & 43 & 29 & 40 & 40 \\
\hline
\end{tabular}

Noot. De percentages zijn per herkomstgroep berekend. ${ }^{a}$ Als percentage van degenen die vertrekken;

b Als percentage van de werkloze vertrekkers.

Bron: Bijwaard, Schluter, \& Wahba, 2014 


\section{Terugkeer van arbeidsmigranten uit Nederland}

Na 5 jaar is al $40 \%$ van de arbeidsmigranten uit ons land vertrokken (Hitzert \& Van Wijk, 2019). Op lange termijn vertrekt driekwart van de arbeidsmigranten uit ons land (Bijwaard, 2010; Bijwaard \& Wahba, 2019). Hoewel arbeidsmigranten uit de nieuwe EU-landen vaak na korte tijd ons land verlaten, is hun vertrek op langere termijn beperkter (zie figuur 2). De arbeidsmigranten uit de westerse landen vertrekken het snelst weer uit ons land. Van deze arbeidsmigranten is 9 jaar na aankomst nog slechts $13 \%$ in ons land, terwijl $36 \%$ van de arbeidsmigranten uit de nieuwe EU-landen na 9 jaar nog in ons land verblijft.

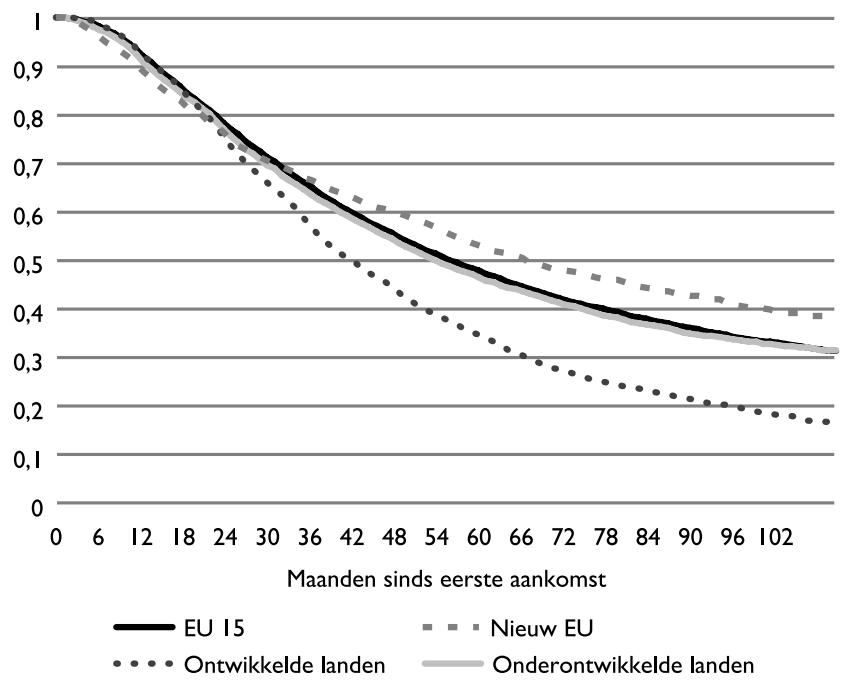

Figuur 2 Kans dat een arbeidsmigrant nog in Nederland is naar lengte van verblijf

Bron: $\mathrm{CBS}$, eigen bewerking

Gemiddeld vertrekt binnen 5 jaar $60 \%$ van de arbeidsmigranten. De vertrekkans om binnen 5 jaar te vertrekken loopt echter sterk uiteen, afhankelijk van de persoonlijke omstandigheden. Zo vertrekken arbeidsmigranten met de laagste inkomens, bijvoorbeeld werkzaam in de bouw, en met de hoogste inkomens, bijvoorbeeld expats, relatief eerder dan migranten met middeninkomens (Bijwaard \& Wahba, 2014). Baanbehoud blijkt een belangrijke rol te spelen bij de vertrekbeslissing: arbeidsmigranten die hun baan verliezen, vertrekken gemiddeld ruim twee keer zo snel (Bijwaard, Schluter, \& Wahba, 2014).

Zowel het arbeidsmarktgedrag als de retourmigratie verschilt sterk naar migratiemotief en naar geslacht. Familiemigranten en vrouwen hebben minder werkervaring en blijven vaker in ons land (Bijwaard, 2010; Bijwaard \& Van Doeselaar, 2014).

Voor de analyse van het retourmigratiegedrag is gebruikgemaakt van een duurmodel. Dat is een model waarbij de verblijfsduur - de tijd tussen de eerste 
aankomst en het vertrek (of einde van de waarnemingsperiode, 31 december 2007, als de migrant niet vertrokken is) - in Nederland de basis vormt. Gebruikelijk voor dergelijke gegevens is om dan een model te schatten voor de vertreksnelheid (hazard; zie: Van den Berg, 2001). Een model voor de vertreksnelheid maakt beter gebruik van het longitudinale karakter van de gegevens dan een model voor de kans dat op een bepaald moment de migrant nog in Nederland is. Een dergelijk model kan namelijk eenvoudig kenmerken meenemen die gedurende het verblijf (kunnen) veranderen, zoals de arbeidsmarktpositie. Daarnaast houdt een dergelijk model rekening met het feit dat de verblijfduren van migranten die op het einde van de waarnemingsperiode nog in Nederland zijn, doorlopen (Bijwaard, 2010; Bijwaard, Schluter, \& Wahba, 2014).

\section{Rekening houden met de selectiviteit van retourmigratie}

Als migranten lang in Nederland blijven teren op een uitkering, zal dat tot hogere lasten voor ons land leiden. Een probleem voor het vaststellen van het effect van werkloosheid op het vertrek is dat migranten die werkloos worden een selecte groep van de arbeidsmigranten vormt. Het is zeer wel mogelijk dat migranten die snel werkloos worden ook eerder geneigd zijn om weer te vertrekken. Daarom is in het duurmodel naast demografische kenmerken, zoals leeftijd, geslacht en jaar van aankomst, ook rekening gehouden met de arbeidsmarktdynamiek (Bijwaard, Schluter, \& Wahba 2014; Bijwaard \& Wang, 2016). Dit houdt in dat de individuele arbeidsmarktdynamiek, dat wil zeggen: de transities van en naar werk, ook gemodelleerd zijn als een duurmodel. De kans op een overgang van werk naar werkloos hangt dus af van de tijd dat men werkend is. Daarnaast is rekening gehouden met eventuele selectie-effecten, dat wil zeggen: factoren die meerdere transities (zowel arbeidsmarkt- als migratietransities) tegelijk kunnen beïnvloeden. Het is bijvoorbeeld zeer wel mogelijk dat een (niet-waargenomen) eigenschap van de arbeidsmigrant, zoals risicozoekend gedrag, zowel leidt tot eerdere werkloosheid als tot sneller vertrek. Als in de analyses geen rekening wordt gehouden met een dergelijk selectieprobleem, zouden we het effect van werkloosheid op het vertrek overschatten. We gebruiken daarom een zogenaamd timing of events-model (Abbring \& Van den Berg, 2003) dat expliciet rekening houdt met selectiviteit.

De resultaten van deze analyse zijn samengevat in figuur 4, dat de proportionele verandering van de vertreksnelheid na werkloosheid weergeeft. Het is duidelijk dat voor alle arbeidsmigranten, behalve voor die uit westerse landen, werkloosheid zorgt voor korter verblijf in Nederland. Figuur 5 splitst dit werkloosheidseffect verder uit naar werkloosheidsduur. Voor arbeidsmigranten uit de EU piekt het werkloosheidseffect op vertrek bij een werkloosheidsduur van 3 tot 6 maanden. Voor arbeidsmigranten van buiten de EU is het werkloosheidseffect meer heterogeen, stijgend in de werkloosheidsduur voor migranten uit niet-westerse landen en een niet-significant effect voor migranten uit westerse landen. 


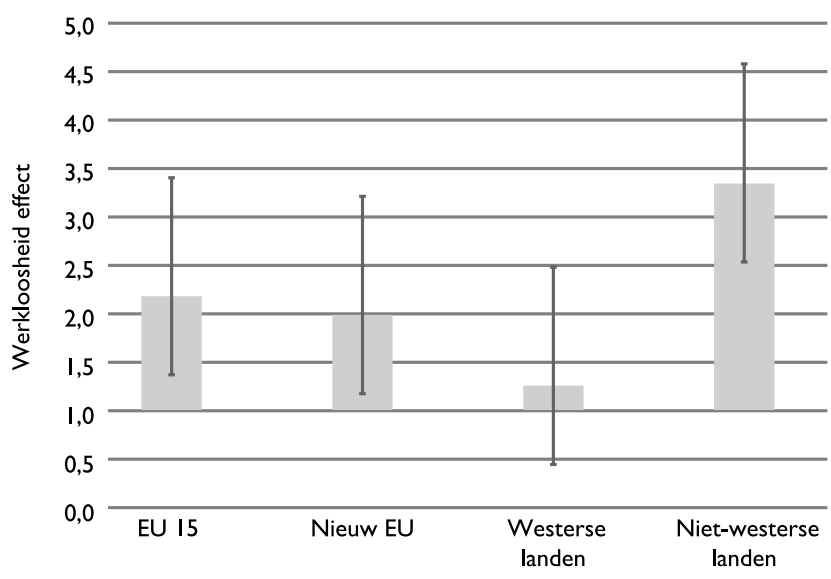

Herkomst

\section{Figuur 3 Invloed van werkloosheid op vertreksnelheid} Bron: Bijwaard et al., 2014

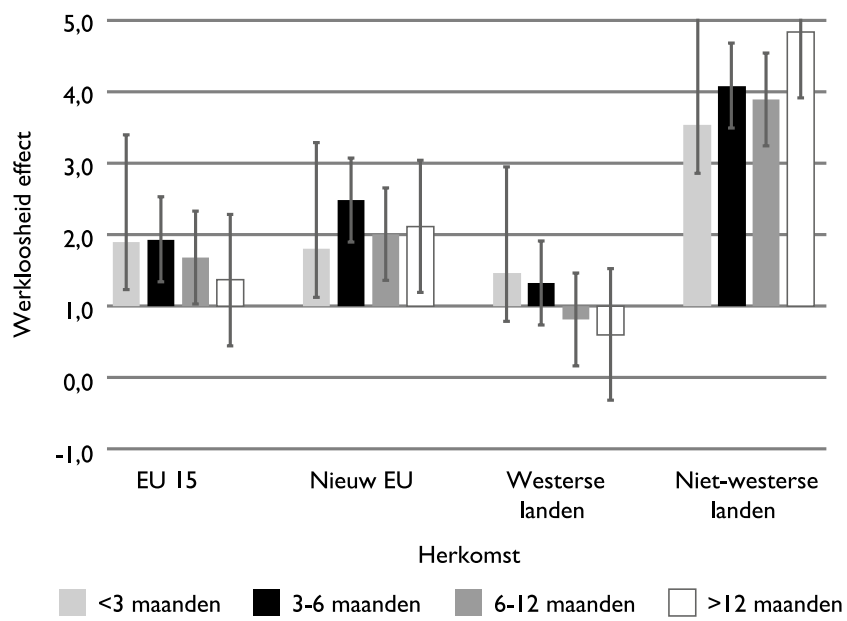

Figuur 4 Invloed van werkloosheid op vertreksnelheid naar werkloosheidsduur Bron: Bijwaard et al., 2014 


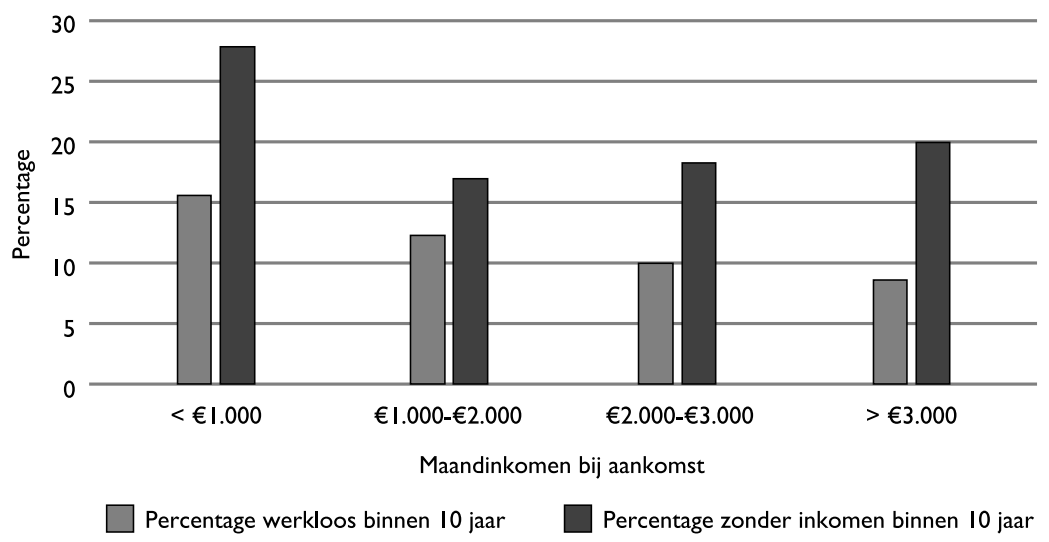

Figuur 5 Arbeidsmarktgedrag naar startinkomen

Bron: Bijwaard \& Wahba, 2014

\section{Invloed van (start)inkomen op vertrek}

Er is maar weinig empirisch onderzoek gedaan naar het effect van de hoogte van het inkomen op de retourmigratiebeslissing. Dit komt voornamelijk door het gebrek aan goede gegevens. De meeste gegevens komen uit kleine surveys, waarin selectieve waarneming en uitval voor grote verstoringen kunnen zorgen. Borjas (1989) en Yang (2006) vinden beiden dat migranten met een hoger inkomen in het gastland minder snel vertrekken. Constant en Massey (2003), en Gibson en McKenzie (2011) vinden echter dat het inkomen geen invloed heeft op de retourmigratiebeslissing.

In een ander onderzoek hebben we onderzocht wat de invloed is van het initiële (maand)loon op het retourmigratiegedrag van arbeidsmigranten uit niet-westerse landen. Daarbij is weer rekening gehouden met de selectiviteit in arbeidsmarktgedrag (Bijwaard \& Wahba, 2014). De immigranten worden wat betreft hun arbeidsmarktsituatie onderscheiden in vier toestanden, te weten: werkend, uitkeringsontvanger, geen Nederlands inkomen en vertrokken naar het buitenland. Arbeidsmigranten die werkloos worden (zie eerder) of geen inkomen ontvangen, zijn eerder geneigd te vertrekken. Het is opvallend dat, volgens de inkomensgegevens van het $C B S$, meer dan de helft van de migranten een periode zonder inkomen in Nederland ervaren. Het merendeel van deze migranten blijft in ons land voor een paar maanden en vertrekt daarna. Het is zeer waarschijnlijk dat veranderingen in de arbeidsmarkttoestand van de migrant samenhangt met migratiegedrag. Het model van Bijwaard \& Wahba heeft daar rekening mee gehouden (zie voor details: Bijwaard \& Wahba, 2014). Figuur 6 laat de relatie tussen startinkomen en arbeidsmarktgedrag in Nederland zien. 


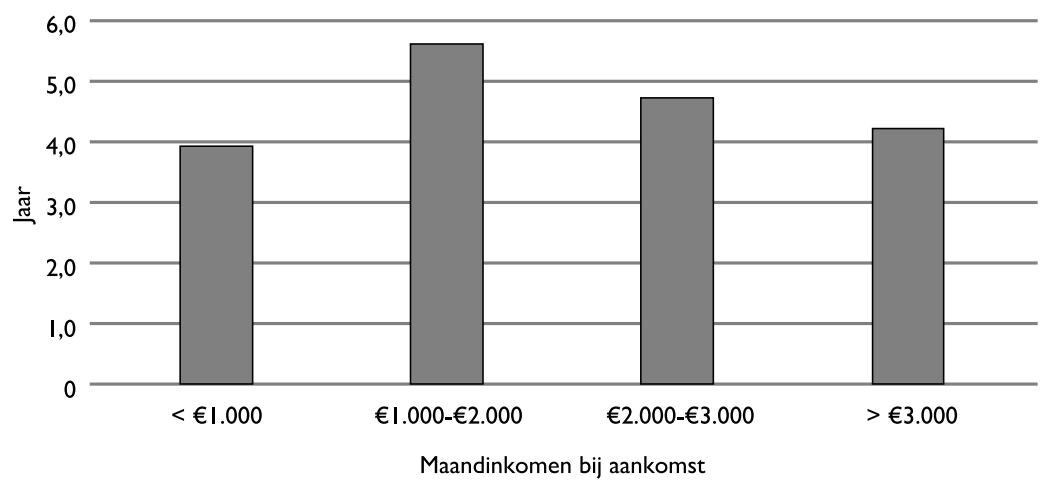

Figuur 6 Verblijfsduur naar startinkomen

Bron: Bijwaard \& Wahba, 2014

De empirische resultaten laten zien dat zowel migranten met een laag inkomen, minder dan $€ 1000$ per maand, als migranten met een hoog inkomen, meer dan $€ 5000$ per maand, sneller vertrekken dan migranten met een middeninkomen. Figuur 6 weerspiegelt dit migratiegedrag in de gemiddelde verblijfsduur in Nederland naar startinkomen. Dus lage-inkomensmigranten lijken met verkeerde verwachtingen aan hun migratieavontuur te zijn begonnen en hoge-inkomensmigranten gedragen zich als ware target savers.

In het onderzoek is ook nog specifiek gekeken naar immigranten uit de belangrijkste herkomstlanden (arbeidsmigranten uit niet-westerse landen), te weten India (19\%), Turkije (11\%), China (10\%), Zuid-Afrika (8\%) en Marokko (3\%). De arbeidsmigranten uit Marokko en China hebben vaker een laag inkomen bij aankomst in Nederland, terwijl Indiërs en Zuid-Afrikanen oververtegenwoordigd zijn in hoogbetaalde banen. Indiërs en Chinezen keren het vaakst weer terug naar het land van herkomst, en Marokkanen en Zuid-Afrikanen het minst. Ook voor deze specifieke groepen van arbeidsmigranten hebben wij een vergelijkbaar U-vormig patroon in de relatie tussen inkomen en terugkeer gevonden (Bijwaard \& Wahba, 2014). Voor alle vijf groepen keren de migranten met het laagste inkomen het snelste terug. Hoewel het verschil in de inkomensverdeling in Nederland ook een rol speelt, zijn de grote verschillen tussen de herkomstlanden in retourmigratie grotendeels te herleiden naar een verschil in het gedrag op de Nederlandse arbeidsmarkt. Zo zijn de Indiërs, over de gehele inkomensverdeling, minder vaak werkloos of zonder inkomen in Nederland dan Marokkanen (Bijwaard \& Wahba, 2014). Het arbeidsmarktgedrag van Chinezen in Nederland is vergelijkbaar met het arbeidsmarktgedrag van Indiërs, en het arbeidsmarktgedrag van Zuid-Afrikanen is vergelijkbaar met dat van Marokkanen (Bijwaard \& Wahba, 2014). 


\section{Ontwikkeling van het inkomen in Nederland}

Het succes van immigranten op de arbeidsmarkt wordt meestal gemeten aan de hand van de groei van hun inkomen tijdens het verblijf in het gastland (Borjas, 1999; Dustmann \& Görlach, 2015). De loongroei staat en valt met arbeidsmarktsucces, dat wil zeggen: of de migrant werkzaam is. Een werkloze heeft immers weinig mogelijkheden om zijn inkomen te verbeteren. Zowel het arbeidsmarktsucces als de loongroei hebben ook invloed op de beslissing om ons land weer te verlaten. Als retourmigratie samenhangt met het arbeidsmarktsucces van de migranten in het gastland, zal het negeren van de onderlinge afhankelijkheid van loongroei, arbeidsmarktsucces en retourmigratie tot een grote vertekening leiden in de interpretatie van de (arbeids)integratie van migranten. Als de minder succesvolle migranten eerder vertrekken, lijkt het of de integratie van migranten stijgt met de verblijfsduur, zelfs als dat niet het geval is, omdat dan vooral de succesvolle migranten achterblijven in Nederland. Als de succesvolle migranten eerder vertrekken, lijkt integratie zich juist minder te voltrekken, omdat dan overwegend de slecht geïntegreerde migranten achterblijven.

Eerder hebben we al laten zien dat arbeidsmigranten die hun baan verliezen met grotere waarschijnlijkheid terugkeren dan arbeidsmigranten met werk. Met andere woorden: wat de vertrekkers gemeen hebben, is het verdwijnen van de reden waarvoor ze naar Nederland zijn gekomen. Ook is aangetoond (Bijwaard \& Wahba, 2014) dat zowel migranten met een laag inkomen als die met een hoog inkomen snel weer uit ons land vertrekken. Zowel arbeidsmarkdynamiek, het vinden en verliezen van een baan, als de hoogte van het inkomen hebben dus invloed op retourmigratiegedrag van migranten, en vice versa. In een recent onderzoek (Bijwaard \& Wahba, 2019) hebben we de loongroei van recente immigranten in Nederland geanalyseerd, waarbij we rekening houden met zowel de arbeidsmarktdynamiek als het retourmigratiegedrag van deze migranten.

In theorie is de loongroei van migranten sterk afhankelijk van de verblijfsduur. Op het moment dat immigranten voor het eerst in Nederland aankomen, hebben ze vaak een tekort aan kennis van de Nederlandse arbeidsmarkt en de Nederlandse taal. Door het verblijf in Nederland zal over het algemeen dit soort kennis stijgen, en daarmee hun productiviteit en hun inkomen. De loongroei van de immigranten kan daarom niet los gezien worden van de lengte van het verblijf in Nederland. Daarnaast speelt de arbeidsmarktdynamiek van de migrant een cruciale rol in de analyse van de loongroei. Alleen als een migrant werkt, kan het loon van die migranten groeien. Een transitie van werk naar werkloosheid zal de loongroei stoppen en een transitie van werkloosheid naar werk zal de loongroei (weer) aanzetten.

We gebruiken weer een duurmodel voor de snelheid van vertrek en de arbeidsmarkttransities. Voor de loongroei definiëren we een log-lineaire regressievergelijking, waarmee de hoogte van het (individuele) inkomen verklaard wordt. Uiteindelijk willen we weten wat de gemiddelde loongroei van de migranten is als we corrigeren voor zowel de arbeidsmarktdynamiek als retourmigratie, die beide mogelijk selectief zijn. Deze selectiviteit is aanwezig, omdat er waargenomen en niet-waargenomen (individuele) factoren zijn die meerdere transities en de loongroei gelijktijdig kunnen beïnvloeden. Het is bijvoorbeeld heel goed mogelijk dat een niet-waargenomen eigenschap van de migrant, zoals ondernemerschap, 
zowel leidt tot eerder verlies van werk, als tot eerder vertrek uit Nederland en een lage loongroei. Als in de analyses geen rekening gehouden wordt met een dergelijk selectieprobleem zou de gemiddelde loongroei van de migrant niet juist geschat worden. Om de invloed van de verschillende selectieprocessen (selectieve arbeidsmarktdynamiek en selectieve retourmigratie) in kaart te brengen, vergelijken we de resultaten van verschillende modellen (Bijwaard \& Wahba, 2019). We onderscheiden drie modellen. In het eerste model (migratiemodel) zijn de individuele snelheid van vertrek uit Nederland en de individuele loongroei van elkaar afhankelijk (zowel via waargenomen kenmerken van de migrant, zoals leeftijd, geslacht, huwelijkse staat, jaar van aankomst en arbeidsmarktsector, als via niet-waargenomen individuele kenmerken). Dit model concentreert zich op de selectieve retourmigratie, maar negeert de arbeidsmarktveranderingen. In het tweede model (arbeidsmodel) wordt juist de retourmigratie genegeerd, en zijn de individuele arbeidsmarkttransities en de individuele loongroei van elkaar afhankelijk. In het derde model ten slotte (volledige model) wordt zowel de arbeidsmarktdynamiek als de retourmigratie meegenomen, waarbij zowel de individuele snelheid van vertrek, de individuele snelheid van arbeidsmarkttransities onderling en van de individuele loongroei afhankelijk zijn.

Een vergelijking van de resultaten van de verschillende modellen vertelt ons in hoeverre selectief retourmigratiegedrag en selectief arbeidsmarktverandering de individuele loongroei van migranten in Nederland beïnvloeden. Als de loongroei in het migratiemodel lager is dan in het volledige model, betekent dit dat de migranten met minder succes op de arbeidsmarkt een lagere loongroei ervaren. Als de loongroei in het arbeidsmodel hoger is dan in het volledige model, betekent dit dat migranten die vertrekken een selectieve groep van migranten vormen, met een hogere loongroei. Hier kunnen we dus uit afleiden in hoeverre de loongroei van migranten (die in Nederland blijven) afhangt van hun arbeidsmarktdynamiek en hun retourmigratiegedrag.

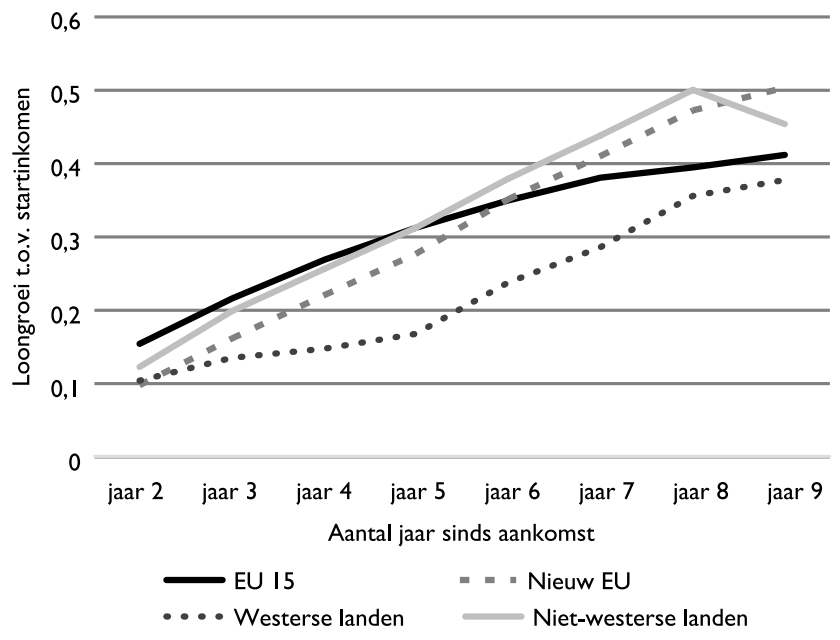

Figuur 7 Loongroei naar herkomst en verblijfsduur

Bron: Bijwaard \& Wahba, 2019 
Het onderzoek laat zien (Bijwaard \& Wahba, 2019) dat negeren van selectieve retourmigratie in het arbeidsmodel leidt tot een overschatting van de loongroei, want de migranten met een hoge loongroei vertrekken sneller uit ons land. Het negeren van de selectieve arbeidsmarkttransities in het migratiemodel leidt tot een onderschatting van de loongroei, want migranten die werkloos worden hebben een lagere loongroei. Figuur 7 geeft de loongroei van arbeidsmigranten naar herkomstregio. Arbeidsmigranten uit de armere landen vertonen de hoogste loongroei, maar de verschillen naar herkomst zijn niet heel erg groot.

\section{Discussie}

Voor een juiste discussie over de instroom van immigranten in ons land dient niet vergeten te worden dat een aanzienlijk deel van deze migranten ons land binnen afzienbare tijd weer verlaat. Uit de empirische analyses van het retourmigratiegedrag van arbeidsmigranten die tussen 1999 en 2007 in Nederland zijn aangekomen, die ik hier besproken heb, blijkt dat dit zowel positief als negatief uit kan pakken. Positief voor de Nederlandse economie is dat migranten die werkloos worden eerder vertrekken, zodat de succesvolle migranten overblijven. Ook blijkt dat arbeidsmigranten met een laag inkomen of een beperkte loongroei eerder ons land verlaten. Negatief voor de Nederlandse economie is echter dat ook arbeidsmigranten met een hoog inkomen en migranten met een hoge loongroei, die een grotere economische bijdrage leveren (meer belasting betalen en meer consumptie), eerder vertrekken. Dit zijn (waarschijnlijk, aangezien het onderwijsniveau van de arbeidsmigranten niet waargenomen wordt) voor een groot gedeelte hoogopgeleide migranten.

Kortom, retourmigratie van arbeidsmigranten in Nederland kan deels verklaard worden uit target-saversgedrag (de succesvolle migranten die snel weer vertrekken) en deels uit retourmigratiegedrag gebaseerd op verkeerde arbeidsmarktverwachtingen (de migranten die vertrekken nadat ze werkloos worden of een lage loongroei ervaren). Ook laten de resultaten van de modellen zien dat het belangrijk is om met selectie-effecten rekening te houden bij de analyse van de invloed van arbeidsmarktgedrag op retourmigratie.

Een belangrijke beperking van de besproken empirische onderzoeken is dat de instroom van arbeidsmigranten na 2007 niet meegenomen kon worden. Ook konden de migranten slechts tot eind 2007 gevolgd worden. Hierdoor is het onzeker of deze analyses het gedrag van de zeer recente arbeidsmigranten weerspiegelt. Ook is daardoor onduidelijk wat de invloed is van de krediet- of coronacrisis op de (selectiviteit van de) retourmigratie van arbeidsmigranten. Toch denk ik dat de analyses ook voor deze groep in grote lijnen overeen zal komen.

\section{Literatuur}

Abbring, J.H., \& Van den Berg, G.J. (2003). The non-parametric identification of treatment effects in duration models. Econometrica, 71, 1491-1517. 
Borjas, G.J. (1989). Immigrant and emigrant earnings: A longitudinal study. Economic Inquiry, 27, 21-37.

Borjas, G.J. (1999). The economic analysis of immigration. In O. Ashenfelter \& D. Card (Eds.), Handbook on the labor economics, Volume 3A (pp. 1697-1760). Amsterdam: North-Holland.

Borjas, G.J., \& Bratsberg, B. (1996). Who leaves? The outmigration of the foreign born. The Review of Economics and Statistics, 78, 165-176.

Bijwaard, G.E. (2010). Immigrant migration dynamics model for The Netherlands. Journal of Population Economics, 23(4), 1213-1247.

Bijwaard, G.E. (2015). Income of immigrants and their return. IZA World of Labor, 2015, 141. doi: 10.15185/izawol.141

Bijwaard, G.E., Schluter, C., \& Wahba, J. (2014). The impact of labor market dynamics on the return-migration of immigrants. Review of Economics \& Statistics, 96, 483-494.

Bijwaard, G.E., \& Van Doeselaar, S. (2014). The impact of changes in the marital status on return-migration of family migrants. Journal of Population Economics, 27(4), 961997.

Bijwaard, G.E., \& Wahba, J. (2014). Do high-income or low-income immigrants leave faster? Journal of Development Economics, 108, 54-68.

Bijwaard, G.E., \& Wahba, J. (2019). Immigrants wage growth and selective out-migration. Oxford Bulletin of Economics and Statistics, 81, 1065-1094.

Bijwaard, G.E., \& Wang, Q. (2016). Return migration of foreign students. European Journal of Population, 32, 31-54.

Chiswick, B.R. (1978). The effect of Americanization on the earnings of foreign-born men. Journal of Political Economy, 86, 897-921.

Constant, A., \& Massey, D.S. (2003). Self-selection, earnings and out-migration: A longitudinal study of immigrants to Germany. Journal of Population Economics, 16, 631653.

Dustmann, C. (1995). Return migration: The European experience. Economic Policy, 22, 214-250.

Dustmann, C. (1997). Return migration, uncertainty and precautionary savings. Journal of Development Economics, 52, 295-316.

Dustmann, C. (2003). Return migration, wage differentials, and the optimal migration duration. European Economic Review, 47, 353-369.

Dustmann, C., \& Görlach, J.-S. (2015). Selective outmigration and the estimation of immigrants earnings profiles. In B.R. Chiswick \& P.W. Miller (Eds.), Handbook on the economics of international migration, Volume 1A (pp. 489-533). Amsterdam: NorthHolland.

Dustmann, C., \& Weiss, Y. (2007). Return migration: Theory and empirical evidence. British Journal of Industrial Relations, 45, 236-256.

Galor, O., \& Stark, O. (1991). The probability of return migration, migrants' work effort, and migrants performance. Journal of Development Economics, 35, 399-405.

Gibson, J., \& McKenzie, D. (2011). The microeconomic determinants of emigration and return migration of the best and brightest: Evidence from the Pacific. Journal of Development Economics, 95, 18-29.

Hitzert, F., \& Van Wijk, M. (2019). Arbeidsmigranten in Nederland: Nieuwkomers op de voet gevolgd. In Statistische Trends. Heerlen/Den Haag: CBS.

Jasso, G., \& Rosenzweig, M.R. (1982). Estimating the emigration rates of legal immigrants using administrative and survey data: The 1971 cohort of immigrants to the US. Demography, 19, 279-290.

Massey, D.S., Arango, J., Hugo, G., Kouaouci, A., Pellegrino, A., \& Taylor, J.E. (1993). Theories of international migration: A review and appraisal. Population and Development Review, 19, 431-466.

Van den Berg, G.J. (2001). Duration models: Specification, identification, and multiple duration. In J.J. Heckman \& E. Leamer (Eds.), Handbook of econometrics, Volume 5 (pp. 3381-3460). Amsterdam: North-Holland.

Yang, D. (2006). Why do migrants return to poor countries? Evidence from Philippine migrants' responses to exchange rate shocks. The Review of Economics and Statistics, 88, 715-735. 